\title{
Welcome to Ireland: Seeking Protection AS AN Asylum SEeker or THROUGH Resettlement-Different Avenues, DIFFERENT RECEPTION
}

\author{
LOUISE KINLEN
}

\begin{abstract}
Ireland accepts approximately 200 resettled refugees each year under the UNHCR Resettlement Programme and a range of supports are put in place to assist the refugees when they arrive and to help their process of integration into Irish society. Roughly ten times this number of asylumseekers arrives in Ireland each year, with some coming from similar regions and groups as the resettled refugees. The reception conditions of both groups however are remarkably different, with a number of grave humanitarian concerns having been raised about the reception conditions of asylum seekers. This article explores the background to refugee reception in Ireland, the current reception conditions of the two groups, how they differ and an analysis of whether such treatment is justifiable.
\end{abstract}

\section{Résumé}

L'Irlande accueille environ 200 réfugiés réinstallés chaque année dans le cadre du programme de réinstallation $d u$ $H C R$, et une variété de mesures de soutien ont été mises en place pour aider ces réfugiés lors de leur arrivée et de leur période d'intégration dans la société irlandaise. Environ dix fois plus de demandeurs d'asile arrivent en Irlande chaque année, y compris certains de régions et de groupes sensiblement les mêmes que les réfugiés réinstallés. Toutefois, les conditions d'accueil des deux groupes sont remarquablement différentes, alors que des problèmes humanitaires graves ont été soulevés en ce qui concerne l'accueil des demandeurs d'asile. Cat article explore le contexte de l'accueil des réfugiés en Irlande, les conditions actuelles d'accueil des deux groupes et leurs différences, et examine si ces conditions d'accueil sont justifiées.

\section{Introduction}

The vast majority of refugees in Ireland begin as an asylum seeker in which they individually seek to have their claim for asylum recognized under the 1951 Convention Relating to the Status of Refugees (Geneva Convention). If such a claim is not recognized at first instance, they may under certain circumstances apply for subsidiary protection or for leave to remain on humanitarian grounds, granted on Ministerial discretion. Whilst one of three forms of residency may ultimately be granted, for the purpose of this paper, this group is referred to as 'asylum seekers'. The term here includes those who are awaiting an outcome on their claim $^{1}$ and are accommodated under the auspices of the Reception and Integration Agency.

In an entirely separate process there are also a small number of people who arrive in Ireland as resettled refugees under the UNHCR assisted resettlement programme. The systems are completely separate and the legal status of both groups cannot be compared. The former (asylum seekers) apply once in Ireland to have a claim for protection or leave to remain recognized and the latter are admitted as refugees, formally recognized so by UNHCR prior to being recommended for resettlement.

The reception conditions of the two groups differ greatly and it is understandable that the two processes require differentiation, with broad recognition internationally that the legal status of an asylum seeker differs from that of a refugee 
whose claim has been formally recognized. ${ }^{2}$ The purpose of this paper is not to question whether differentiation in their reception conditions is justified, but rather to ask whether the extent of such differentiation is justified and proportionate.

Even without comparison to the reception conditions of resettled refugees, the conditions of asylum seekers arriving in Ireland have given rise to a range of humanitarian and human rights concerns, which have been documented widely. ${ }^{3}$ Ireland has not adopted the EU Directive on Laying Down Minimum Conditions for the Reception of Asylum Seekers, 2003 and differs from most other EU Member States (except Denmark) in terms of not granting asylum seekers the right to work until they receive a positive outcome on their application or are given alternative leave to remain, regardless of the duration of the process. Asylum seekers are housed in hostel accommodation for up to seven years in a system known as Dispersal and Direct Provision in which they receive three meals a day and a very small weekly allowance, which has not increased since its introduction in 2000. ${ }^{4}$ Ireland has also been criticized by the international community for having the lowest recognition rates of asylum claims in Europe. ${ }^{5}$

In a parallel process Ireland is one of thirteen EU Member States $^{6}$ that have participated in the United Nations High Commissioner for Refugees (UNHCR) supported resettlement programme, in which states agree to accept a quota of refugees deemed suitable for resettlement each year. Ireland currently agrees to accept a quota of 200 refugees per year under this system. ${ }^{7}$ Ireland is proud of its humanitarian response to worldwide crisis situations and has assisted other countries considering participation in the UNHCR resettlement programme.

Asylum seekers seeking protection under the Convention are not legally treated as refugees until their claim for refugee status has been formally recognized under the Convention. They are not considered to be refugees under the definition of the Convention if granted subsidiary protection $^{8}$ but in practice are granted similar entitlements. ${ }^{9}$ Those granted leave to remain on humanitarian grounds are granted so at Ministerial Discretion and generally for a temporary period, subject to renewal. Resettled refugees on the other hand have been formally recognized by the UNHCR as refugees having protection needs and meeting specific criteria that make them suitable for resettlement. ${ }^{10}$ Other resettlement countries however, such as Sweden or Finland offer similar reception and integration programmes for asylum seekers and resettled refugees. ${ }^{11}$ It is argued in this paper, that the extent to which (and length of time) the Irish State deliberately excludes asylum seekers from the humane reception conditions and integration supports as afforded to resettled refugees is disproportionate. The treatment of asylum seekers has been recognized by some commentators as a breach of a number of norms of international human rights law, particularly with regard to social and economic rights and the lack of personal autonomy and freedom. ${ }^{12}$ Particular concerns have also been raised in relation to the impact on children and families, including the unsuitability of the environment for raising children. ${ }^{13}$ Those who obtain refugee status are entitled to some integration and reception supports, but I would argue that the time period required in waiting is often too long and the process of de facto integration has already begun and it is difficult to conceptualize a process of 'reception' after having spent several years in the country.

\section{Is It Appropriate to Compare the Reception Conditions of Resettled Refugees and Asylum Seekers?}

The reception conditions of these two groups of refugees are entirely different and differentiation is reasonable based on the different avenues of arrival and legal status. It is argued here however, that such extreme differences in treatment are disproportionate and send contradictory and confusing messages in relation to which refugees are genuine and deserving and those that are 'bogus' or 'fraudulent'. ${ }^{14}$ Currently Ireland operates a dual system in which the asylum procedure must first be exhausted before other claims for protection can be made. ${ }^{15}$ It is proposed however to bring the laws in line with European norms through the introduction of a single protection procedure in which an application for asylum and subsidiary protection can be made at the outset. ${ }^{16}$ Currently the dual process and the requirement to exhaust the asylum claim procedure before applying for other forms of protection mean that the legal process can be very lengthy and cumbersome.

There are however a number of ways in which the processes of resettlement seeking asylum intersect and de facto comparisons are made by both the groups themselves, local communities and service providers. This intersection, which emerged in two separate research projects led to the questioning of why their reception differs so greatly. Some of the factors that led to posing this question included the following:

Firstly, Ireland is a small country and for both resettlement and asylum seekers, a policy of dispersal throughout the country and outside the capital city is in operation. Asylum seekers and resettled refugees may therefore be housed in the same or nearby small towns where they come into contact with each other and the distinctions between the two are not always understood by the groups themselves, local communities or some service providers, especially when the groups may come from the same geographical or 
ethnic backgrounds. This was confirmed in research interviews in both research projects and feelings of jealousy and resentment existed, particularly where they were housed close to each other. ${ }^{17}$

Secondly, whilst Convention refugees (with recognized status) have a similar legal status to resettled refugees in terms of entitlements to work, education, social welfare etc., official reception programmes are not organized in the same way and intensive language training is only offered in areas with significant populations of refugees. Orientation training as offered to resettled refugees is not available to Convention refugees. It is also difficult to conceptualize a process of 'reception' when a person has already been living in a country for several years. Whilst it can be argued that entitlements will be granted once a claim for asylum is recognized and that it is a matter of temporality rather than an absolute lack of entitlements, it is impossible to ignore that three to seven years of a person's life can be very lengthy and their openness to reception programmes after this period is likely to be different than someone who has recently arrived.

I would argue contrary to official discourse that the process of initial adaptation and reception takes place and therefore commences during the phase as an asylum seeker and not after the granting of refugee status, which is several years later and the process of reception and partial integration has already commenced. The former National Consultative Committee on Racism and Interculturalism in its submission on refugee integration argued equally that integration supports should be provided during this initial reception phase due to firstly the potential consequences of not including asylum seekers (including loss of self-esteem, inability to use skills or contribute to local society) and secondly due to the de facto partial integration of asylum seekers. ${ }^{18}$ They argued that this dichotomy results in:

... a form of partial integration which takes place, but this integration is unplanned; uncoordinated; and largely unsupported, except for the work of the community sector and the basic 'safety net' entitlements for health, social welfare and education. ${ }^{19}$

Reception by its nature, which refers to the act of receiving within the country, operates during the period when the refugees or asylum seekers first arrive in the country or at least after six months. The organization of reception type supports after the recognition of a claim of asylum (or other forms of protection) can also be difficult as such claims are decided on an individual basis and group programmes therefore more difficult to organize. There is also some evidence to suggest that negative memories of the period spent as an asylum seeker can impede future integration in the host country. ${ }^{20}$
Thirdly, the official discourse in Ireland surrounding asylum seekers is one that seeks to exclude ${ }^{21}$ and asylum seekers are excluded from the brief of the Office for the Promotion of Migrant Integration. ${ }^{22}$ Previously the Reception and Integration Agency had joint responsibility for the reception of asylum seekers and the resettlement programme. This sometimes caused confusion with service providers who saw some agency staff with responsibility for both areas. Official documents and policies refer to accommodation and services available during the time that asylum seekers await a decision on their application, under the pretext that it exists only as a very temporary situation, and do not necessarily take cognizance of the fact that Ireland becomes a de facto home for many people who may spend several years in such a situation and partial integration does begin to take place. The official argument that reception and integration programmes should begin once a person has received official recognition of their status as a refugee can be difficult to justify in practice, when several years of a person's life have been spent living in Ireland (without the right to travel elsewhere ${ }^{23}$ and links and contact with their country of origin may be diminishing) and they have adopted their own strategies and coping mechanisms in navigating the system.

Fourthly, in what Hathaway refers to as 'Government obfuscation', Governments such as Australia (and Ireland) commit to resettle a certain number of refugees due to the success of the Government in curtailing 'illegal refugee arrivals' ${ }^{24}$ This dichotomy of transferring resources away from 'undeserving' asylum seekers towards 'deserving' resettled refugees is problematic and clearly signals a desire for an orderly and controlled process of refugee protection as opposed to the messy and complex realities involved in undertaking journeys to seek asylum. Resettled refugees generally also experience complex and harsh conditions in their journeys to and time spent in the refugee camps where they are referred for resettlement. Such hazards however are generally not the preoccupation of the Irish Government and the assistance of UNHCR and IOM simplify the process and their subsequent journey into Ireland.

It is therefore argued here, that contrary to official discourse, the process of reception as a precursor for integration comes into play once a person arrives in the country or at least within six months of arrival. The UNHCR has also argued that access to the labour market should be granted within a maximum period of 6 months, ${ }^{25}$ with such a provision also contained in the EU Reception Conditions Directive. ${ }^{26}$ The exclusion of asylum seekers from early integration supports has been found to ultimately affect their long-term integration ${ }^{27}$ and the 'best interests' of the child 
principle enshrined in the UN CRC is not served through such a prolonged period of institutionalization.

Questions also arise in relation to States' determination and definition of who constitutes a refugee deserving of protection and Ireland's very low recognition status sug gests that this is interpreted very narrowly. It has also been argued that the Geneva Convention does not distinguish between asylum seekers and refugees and that states use the term 'asylum seeker' to deny refugee status. ${ }^{28}$ The lengthy determination process and legal complexities often mean that people are left in this category of 'asylum seeker' for long periods of time.

Scholarly attention to the comparison of these two groups has been very limited and Ireland offers an interesting case study of a relatively generous resettlement programme on one hand versus a policy of containment and deterrence towards asylum seekers.

The questions that I attempt to address in this paper are:

1. In what ways do the reception conditions for asylum seekers and resettled refugees differ?

2. Is the extent of such differential treatment proportionate?

\section{Methodology}

This paper is based on the culmination of research and analysis from a number of different sources. Firstly, research was carried out during 2007-2008 in relation to resettled refugees and the integration supports they receive. Secondly, research currently being undertaken in relation to asylum seeker reception policy presented a stark contrast to the high levels of support experienced by resettled refugees. Whilst the two research projects are entirely separate, this led to a questioning of why Ireland treats the two groups so differently and whether it is possible to carry out comparative analysis.

Firstly, I carried out an in-depth review was carried out on the reception, orientation and integration of resettled refugees in Ireland under a European Refugee Fund transnational project on behalf of the Reception and Integration Agency. ${ }^{29}$ Fieldwork carried out as part of this review involved in-depth interviews with 33 resettled refugees and focus groups and interviews with a wide range of support agencies from the statutory and voluntary sectors. The research examined inter alia the role of orientation and reception programmes for resettled refugees in three towns in Ireland and the extent to which the process of integration had begun. ${ }^{30}$ Whilst the focus of this research was primarily on resettled refugees, the issue of asylum seekers and their interactions both with resettled refugees (including marriages and relationships between the two groups) and with statutory and voluntary agencies emerged in the research interviews. The research also demonstrated how early reception and integration supports (including intensive English language tuition) were very beneficial and aided the process of integration.

Secondly, I am currently completing doctoral research on the role of NGO advocacy in influencing public policy making in relation to the reception conditions of asylum seeking families and children. In addition to extensive documentary analysis of policy documents, Government debates and relevant literature, in-depth qualitative interviews have been conducted with twelve key voluntary sector organizations attempting to influence policy in relation to asylum seekers and ten key policy makers and funding organizations. This research does not focus on resettled refugees per se, but the interviews conducted have also confirmed the exclusionary nature of asylum reception policy and the discontent of many NGOs and some civil servants in Government departments other than the Department of Justice. ${ }^{31}$ In-depth results from this research are not presented here, but the interviews and documentary analysis were very useful in terms of highlighting Government policy and discourse in relation to asylum seeker reception.

\section{Reception in an International Context}

The term 'reception' is used both with reference to asylum seekers and resettled refugees both in national and international policy documents. ${ }^{32}$ The reception of asylum seekers forms a large part of EU asylum policy and the EU Council Reception Conditions Directive requires Member States to 'take into account the specific situation of vulnerable persons such as minors, unaccompanied minors, disabled people, elderly people, pregnant women, single parents with minor children and persons who have been subjected to torture, rape or other serious forms of psychological, physical or sexual violence' and to provide for the right to work within one year of lodging a claim for asylum. ${ }^{33}$ The UNHCR also refers to 'reception' in the context of the asylum process and in their Discussion Paper on Recommended Reception Standards for Asylum-Seekers in the Context of the Harmonization of Refugee and Asylum Policies of the European Union, ${ }^{34}$ they point to the principles of non-refoulement and non-discrimination as underpinning adequate reception policies. They also make reference to the ICCPR and the ICESCR, which prohibit discrimination on the grounds inter alia, of national origin. The paper also emphasizes the duration of the period during which people await a decision on their claim for refugee status and recommends that asylum-seekers should be entitled to a broader range of benefits if the process is prolonged. The refusal of the Irish Government to allow asylum seekers to work was however based primarily on deterrence 
and ensuring that the asylum system does not create any further "pull factors". 35

A dichotomy appears to have emerged with a liberal and protective approach to the reception of resettled refugees. Research interviews with resettled refugees in the first project confirmed that this process is beneficial and such integration supports are greatly appreciated. ${ }^{36}$ On the other hand Ireland's system for the reception of asylum seekers has evolved from a relatively liberal to one, which could now be classified as restrictive, discriminatory and operating within a discourse of exclusion and deterrence. ${ }^{37}$ It is also acknowledged that even in the context of official discourse on 'integration', its linkages to security and immigration control and the division of various forms of desirable migrants are ever present. ${ }^{38}$

\section{Background to the Reception of Refugees in Ireland} The Arrival of the First Refugees in the 1990s

Prior to the 1990s, the numbers of people arriving in Ireland to seek asylum was very low, with most of the refugee arrivals coming through organized refugee programmes. Unlike other countries, which took in large numbers of refugees following World War II, Ireland accepted very few refugees at this time. It acceded to the Convention on the Status of Refugees in 1956 and in the same year accepted 539 Hungarian refugees which had fled following the failed uprising. This was followed by a small group of Chilean refugees in 1973, 212 Vietnamese refugees in 1979 and 455 Bosnian programme refugees from 1992-1998. For most of these refugees, the supports they received were very minimal, with little English language and other educational or integration supports. In the past, Ireland did not have an established tradition of being a receiving country for asylum seekers or refugees in comparison with other European countries. This was partly due to geographic, political and economic isolation ${ }^{39}$ and the fact that Ireland was a small island and not traditionally an access point for people fleeing conflict.

In the 1990s Ireland began to experience a new phenomenon of larger numbers of people arriving spontaneously in the country to seek asylum, leading to a peak in 2003 and declining ever since. The number of applicants received by the Office of Refugee Applications Commissioner (ORAC) since 1991 can be broken down as in figure 1 .

The mid to late 1990s proved to be a difficult time as the Irish State struggled with establishing a system for processing asylum applications and receiving and housing asylum seekers arriving on its shores, a system which had heretofore been almost non-existent. The Refugee Act was introduced in 1996 and this set some foundations for how Ireland might regulate the process, but was still enacted at a time when numbers were still relatively low. Whilst the Refugee Act, 1996 was considered a relatively liberal piece of legislation in comparison with other EU States, tighter controls were put in place through the amendments of legislation such as the Aliens Act, 1935 thus giving greater powers to the immigration authorities and gradually creating a less liberal and more restrictive system of asylum. ${ }^{40}$

Figure 1. Number of Applications Received at ORAC from 1991 to 2010.

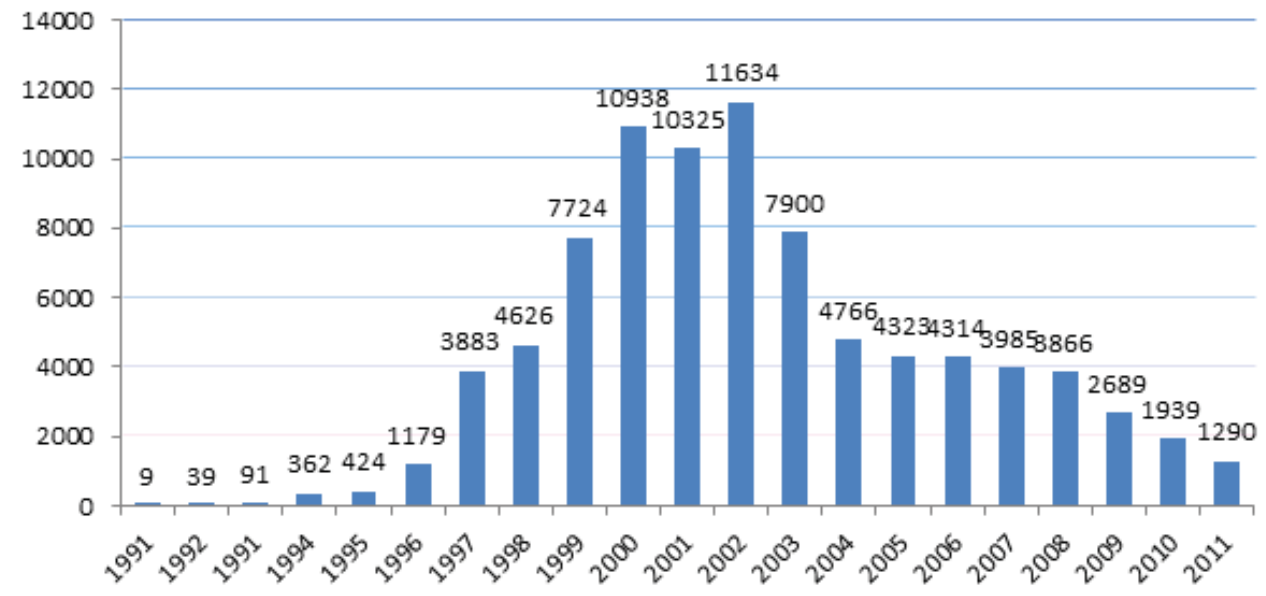

Source: RIA, Annual Report 2011, Dublin: Reception and Integration Agency, (2011) http://www.ria.gov.ie/en/RIA/RIA\%20 Annual\%20Report\%20(A3)2011.pdf/Files/RIA\%20Annual\%20Report\%20(A3)2011.pdf (accessed June 24, 2012). 
The Early 2000s-Immigration, Citizenship and the Right to Belong

The period of 2000-2004 could be described as somewhat of a crisis point for the Irish Government as it grappled with coping with relatively large numbers of asylum seekers arriving on its shores (compared with previous numbers), an emerging but still underdeveloped asylum claim processing system, a general lack of understanding and awareness of refugee issues among the Irish public, few measures of integration and concepts of citizenship and belonging that were changing. There were a number of ways in which the Government sought to curtail this growth and limit the attractiveness of Ireland as a destination for asylum seekers.

One of the ways in which the Irish Government sought to differentiate between asylum seekers and their rights to belong in Ireland compared with 'nationals' of Ireland was through changing the laws of citizenship and who is entitled to it. A referendum in 2004, which changed the laws of citizenship, thus removing the automatic right of children born to non-national parents, has been judged as the most significant event in the politics of immigration in Ireland when: 'constitutional definitions of Irishness narrowed at a time when the composition of Irish society had broadened significantly through immigration'. ${ }^{41}$

\section{Current Reception Conditions for Asylum Seekers and Resettled Refugees}

Asylum Seekers Reception

A parallel way in which the Irish Government sought to limit the number of asylum-seekers coming to its shores was the gradual erosion of socio-economic rights and entitlements afforded to asylum seekers. The reception conditions were altered radically during the period 1999-2002 and the commencement of the Dispersal and Direct Provision Scheme in 2000 signified the start of a campaign to make life as an asylum-seeker more difficult and therefore less attractive to other potential asylum-seekers. When asylum seekers first started arriving in Ireland during the1990s, welfare benefits were provided, based on the criteria of need, similar to that of Irish citizens and they were entitled to live in independent accommodations, supported by the Government. By 1999 however, there was considerable pressure on the
Government and a view held by many politicians that the system was too costly, conditions were too good and that it was likely to create a 'pull factor'. There was also a concern that too many asylum seekers were located in the capital and there was considerable pressure put on the housing system and there was a fear that emergency accommodation could no longer be provided and asylum seekers and others seeking housing could face homelessness. ${ }^{42} \mathrm{~A}$ specialized agency called the Reception and Integration Agency (RIA) was established and given responsibility for the reception of asylum seekers. The 'integration' element of the unit however, was confined to Convention and Resettled refugees. ${ }^{43}$ This function was subsequently moved to the Office for the Promotion of Migrant Integration, thus rendering the 'integration' part of the Reception and Integration Agency largely defunct.

In April 2000 Ministerial Circular 04/00 was issued by the then Department of Social and Family Affairs, which effectively created the system of Dispersal and Direct Provision. This system was introduced just a few weeks after a similar system was established in the $\mathrm{UK}^{44}$ and it was officially introduced to address the shortage of accommodation in Dublin and enabled Ireland to fall in line with other EU states that had introduced similar policies. ${ }^{45}$ In addition to dispersing asylum seekers throughout the country and away from Dublin, it also introduced the policy of direct provision where asylum seekers were no longer entitled to regular welfare payments, but were provided with basic food and shelter and an allowance of $€ 19.60$ per adult and $€ 9.60$ per child per week.

These rates have not changed since the introduction of the system in 2000. Initially some other supplementary allowances were still available such as child benefits, disability allowance and other family support payments. The introduction and application of the Habitual Residence Condition (HRC) through Section 246 of the Social Welfare (Consolidation) Act 2005 played a major role in diminishing the welfare supports to which asylum seekers were entitled to. The HRC was originally introduced to prevent welfare tourism when the new accession states joined the EU and prevents those who are not 'habitually resident' in Ireland from claiming a range of welfare benefits. Following some

Table 1. Decisions on Asylum Applications 2011

\begin{tabular}{|c|c|c|c|c|c|c|}
\hline & Total Decisions & $\begin{array}{l}\text { Total Positive } \\
\text { Decisions }\end{array}$ & $\begin{array}{l}\text { Refugee Status } \\
\text { granted }\end{array}$ & $\begin{array}{l}\text { Subsidiary } \\
\text { Protection } \\
\text { granted }\end{array}$ & $\begin{array}{l}\text { Leave to } \\
\text { remain for } \\
\text { humanitarian } \\
\text { Reasons }\end{array}$ & $\begin{array}{c}\% \text { Total Positive } \\
\text { Decisions }\end{array}$ \\
\hline EU27 & 365615 & 84110 & 42680 & 29390 & 12040 & $23 \%$ \\
\hline Ireland & 2605 & 150 & 135 & 15 & 0 & $5.20 \%$ \\
\hline
\end{tabular}


uncertainty surrounding its application to asylum seekers, the Social Welfare and Pensions (No. 2) Act was introduced in 2009, containing a blanket exclusion of all persons in the asylum process from being considered 'habitually resident'. ${ }^{46}$ As a result asylum seekers are no longer entitled to a range of other benefits other than their basic weekly allowance.

Another hallmark of the Irish system has been the low rate of positive recommendations, both at first instance and for subsidiary protection and humanitarian leave to remain. Table 1 outlines the recognition rates at the various stages in Ireland and across the EU27 in 2011, showing Ireland's rate of only $5.2 \%$ of positive decisions, compared with an EU average of $23 \% .{ }^{47}$

\section{Humanitarian Concerns}

A number of concerns have been raised about the conditions of direct provision and the legal basis on which it was established. These have been widely documented and some of the principal concerns are outlined below:

1) Through the introduction of the HRC and the exclusion from a range of benefits available to the general population, asylum seekers were further marginalized and at risk of social exclusion. They are also excluded from a wide number of national poverty and budgeting surveys as they do not fit the category of a 'household'. ${ }^{48}$ Despite a decade of a range of far-reaching strategies to deal with social issues such as racism, poverty and social exclusion and improved outcomes for child well-being, asylum seekers appear to have been implicitly excluded from such measures. ${ }^{49}$ A clear example is the overarching vision articulated in the National Children's Strategy of an Ireland where 'all children are cherished and supported by family and the wider society; where they enjoy a fulfilling childhood and realize their potential. ${ }^{50}$ The research on asylum reception policy also raised this dichotomy, with one Immigration NGO research participant recalling how a phone call to a Government office dealing in relation to how the NCS applies to asylum seeking children and those born in Ireland was met with the response that it does not apply to 'those children'. Senior civil servants in Government departments other than the Department of Justice also raised the issue of how service providers at a local level can sometimes be unsure of the exact entitlements each group has and how the policy of Direct Provision can mitigate other policy goals such as the health and well-being of the population. ${ }^{51}$

2) The system is now over ten years in operation, with very few of the concerns raised during this decade and very little has changed, with many of the concerns raised in reports in the early stages ${ }^{52}$ still existing and in many ways the system has deteriorated further and there is more widespread recognition of the human rights abuses within the system. ${ }^{53}$ Issues that have persisted during this time are numerous and include low levels of financial support, which have not increased with inflation, overcrowding, long periods spent in direct provision whilst awaiting a decision, denial of the right to work or take part in education for the who duration of the time spent awaiting an assessment of an asylum claim, dietary and health concerns, exclusion and discrimination. Human rights concerns include violations of housing rights and right to adequate standard of living (Article 25 UDHR, Article 11 ICESCR) and rights to family life (e.g. Article $8 \mathrm{ECHR}$ ), principle of non-discrimination (e.g. Article 2, UDHR), and the right to work (e.g. Article 6 ICESCR and the EU Reception Conditions Directive). Whilst there may be derogations permitted to some rights on the grounds of national security or the preservation of the public good, a defense invoked by the Department of Justice, it is argued that the withdrawals and reduction particularly of social and economic rights is disproportionate. Such policies of exclusion have been justified on the grounds of preserving immigration controls and protecting the welfare state from those who are seen as not having a right to be in the country and the State continues to impose stratifying and restrictive policies. ${ }^{54}$

3) A key concern that existed particularly at the beginning lay with the system of dispersal, which saw the creation of 60 accommodation centres in 24 counties in Ireland, ${ }^{55}$ many of which were in small and isolated rural towns and villages, with no history of inward migration or diversity. Unlike other countries such as Sweden, where the local municipalities undergo an intensive period of preparation and are actively involved in the reception of asylum seekers and refugees, ${ }^{56}$ very little or no consultation was undertaken with the vast majority of villages/towns where the asylum seekers were to be located and a policy of secrecy operated about the location of such hostels and a deliberate lack of prior consultation with the relevant authorities and service providers, for fear of a backlash or unwillingness to co-operate. ${ }^{57}$

4) The impact of the system on children has been detrimental and there are a number of key concerns involving children's rights and welfare. Children living in direct provision are usually dependents of adult asylum seekers, although some have applications made on their own behalf. Some arrived with their parents and others were born into the system of direct provision and it is the only life they know. Breen has argued that the system disregards the rights of the child and that in relation to Irish-born children, their rights depend on the nationality of their parents, 'which runs contrary to the non-discrimination provisions of national and international law regarding the rights of 
the child and the protection to be accorded to the family unit'. ${ }^{58}$ Despite ratification of the UNCRC in 1992, a number of human rights concerns have been raised in relation to the treatment of children and families, including violations of the rights to family life, privacy and parental rights. ${ }^{59}$ Basic health and nutritional concerns for children have also been highlighted, especially concerning the rationing and control of food and lack of autonomy of parents to provide alternatives. Children in direct provision appear to be excluded from many Government strategies outlining goals for children and the recent proposed wording of the constitutional amendment on children's rights was deferred, partly based on an intervention by the Department of Justice which expressed concern in relation to the resource implications of applying the best interest of the child principle in cases concerning asylum seeking children. ${ }^{60}$ Whilst the Geneva Convention is relatively silent on children's rights, it has also been argued that it should be read in the light of the UNCRC. ${ }^{61}$ The Committee on the Rights of the Child has also noted that State concerns in relation to immigration control cannot overrule the best interests of the child principle. $^{62}$

The system is hallmarked by one of "enforced idleness" that often persists for several years. Asylum-seekers are entitled to very basic subsistence and even this can be lacking. ${ }^{63}$ The long-term impact this may have on children who do not experience role models of their parents being able to work, train or provide for their family is also a cause for concern. This is further compounded by mental health difficulties that can arise both from previous situations of persecution, concerns about other family members and a system that affects people's overall well-being and selfesteem. ${ }^{64}$ English lessons (other than at a very basic level) and other integration supports are not provided and asylum seekers are excluded from all Government initiated integration measures. NGOs working with asylum seekers increasingly find it difficult to use public funds for the purposes of assisting asylum seekers. ${ }^{65}$ Various NGOs and intergovernmental organizations and human rights bodies have made calls to overhaul the system, ${ }^{66}$ yet the Irish Government has repeatedly refused to do so and recently published a Value for Money Review of the system of Direct Provision, which concluded that the system is still producing 'value for money' and therefore should remain. The review however failed to examine the long-term impacts of the system on people's health and well-being and potential health related costs. ${ }^{67}$ Following the election of the new Government in March 2011, no substantial changes have yet been made, despite pre-election promises of the new coalition partners to amend the system and it would now appear that budgetary concerns prevail in the current fiscal climate. ${ }^{68}$ Some reform of the asylum application and processing system however is anticipated in the new Immigration Residence and Protection Bill.

\section{Reception and Orientation for Resettled Refugees} Overview of Resettlement in Ireland

The reception conditions and overall treatment of resettled or 'programme' refugees operate in stark contrast to those of asylum seekers. The resettlement process comes into play when the UNHCR considers that the other two durable solutions of voluntary and safe repatriation to the country of origin or local integration have been exhausted. There are currently twenty five countries worldwide who participate in resettlement programmes in partnership with the UNHCR, including Ireland. Participation in the resettlement programme is voluntary and there is no legal obligation to do so under international law.

In 1998 the Irish Government agreed to participate in the UNHCR Refugee Resettlement Programme. This Decision was taken following approaches by the UNHCR requesting that Ireland would admit, on an annual basis, a number of "special cases" refugees who do not come under the scope of Ireland's obligations under the Geneva Convention of 1951 as amended by the New York Protocol of 1967. Initially Ireland agreed to accept 10 cases (approximately 40 persons) per year and this was later increased to 200, following a Government decision in 2005. In recent years however, this quota has not been reached and for example in 2011 only 45 refugees were resettled to Ireland.

The resettlement process differs in many ways to the asylum process in that those selected to come to Ireland are already recognized as refugees and as a condition of resettlement are granted long-term residency in Ireland. Whilst there has been some commitment on behalf of the Irish Government to participate in the programme, the numbers of refugees it accepts each year has been contingent on lowering the numbers seeking asylum in Ireland. ${ }^{69}$

Although the channels through which resettled refugees and asylum seekers arrive are very different and their treatment is completely separate, some asylum seekers to Ireland may also come from similar ethnic groups and geographic regions as the resettled refugees (e.g. Sudanese, Iranian Kurds and Congolese). ${ }^{70}$

Whilst Ireland has been taking part in the UNHCR resettlement programme for over ten years, the numbers have been relatively small and it generally has not generated much controversy or debate, and has largely been absent from newspaper headlines, Dáil (Parliament) debates and academic literature. ${ }^{71}$ In cases where the subject of resettled refugees have been reported on by the media or by politicians, there has never been any questioning of the validity of their 
right to be present and receive assistance from Ireland and much reporting/debates have adopted a sympathetic stance to their plight. ${ }^{72}$ Policy discourse in relation to resettled refugees also adopts a stance of sympathy and efforts are made immediately (both pre and post-departure) to assist their integration.

Current Reception Conditions for Resettled Refugees Resettlement in Ireland is generally organized through a three-stage process. The first stage is Selection, which is either carried out by in-country selection missions in the country where the refugees are located or through the dossier method. Since 2005 Ireland has carried out selection missions to Jordan (Iranian Kurds), Thailand (Burmese Karen), Uganda (Sudanese), Bangladesh (Burmese Rohingya) and Tanzania (D. R. Congolese). ${ }^{73}$ During the selection missions, pre-departure orientation may also take place where the would-be resettled refugees participate in training about the resettlement process in Ireland and cultural orientation information. The evaluation and piloting of such pre-departure orientation training found that it could be a very useful tool in helping people to prepare for the journey, but that the focus of many people at that stage was on moving "away from" their current situation rather than "moving towards" anything specific and the timing of such training before the completion of the selection process sometimes meant they were too focused on that process to fully concentrate on the pre-departure training. ${ }^{74}$ Nevertheless such training offered resettled refugees some opportunity to prepare for their departure to their new destination.

The second stage is called The Reception Programme where the resettled refugees are housed in a purpose built centre for a period of six weeks where they undergo intensive cultural orientation training, whose purpose is to "prepare them for independent living in the community" ${ }^{75}$ Such training is provided in conjunction with various service providers and covers a wide range of topics and introduces key English terms that the refugees are likely to encounter while in living in Ireland. Children under 18 participate in a separate induction programme that prepares them for mainstream education. The evaluation of the orientation programme found the process to be very beneficial and most interviewees found that it had given them a good introduction to Irish life and culture. ${ }^{76}$

The third phase is now termed Resettlement and Integration and involves a period of one year to 18 months where language tuition of 20 hours per week is provided, as well as some support and monitoring through a refugee support worker, usually based in a local development agency. Resettled refugees are usually housed in independent accommodation in the community, with each group usually allocated to a small town. The towns are chosen in advance and the Office of the Promotion of Migrant Integration works closely with the local authorities to ensure that various supports are put in place. Notwithstanding this, Ireland still operates a mainstream approach to integration in which service providers are expected to meet the needs of diverse communities through existing budgets and they need to equip themselves with the means to deal with different communities. ${ }^{77}$ Whilst integration of resettled refugees is far from being unproblematic, the type of supports such as language training, refugee support workers and overall monitoring of their integration greatly exceed those afforded to asylum seekers. Whilst Convention Refugees and those with Subsidiary Protection may receive some additional supports and are granted the right to work, language training can be difficult to access if not in a large centre and organized cultural orientation programs are not provided in the same manner. ${ }^{78}$

\section{How Do the Reception Conditions of Asylum- Seekers and Resettled Refugees Differ?}

There are clear legal differences between the two groups and their legal status per se is not comparable. An asylum seeker has arrived in Ireland for the purpose of seeking protection under the Geneva Convention, and it is incumbent on him/her to prove he/she cannot due return to his/her country of origin owing to a well-founded fear of persecution. As explained above, this process can be very lengthy and the current dual system of not being entitled to apply for other forms of protection at the initial stages can protract the process. A resettled refugee on the other hand has been formally recognized as a refugee by UNHCR and is outside his/her country of origin when recommended for resettlement to a third country. It is not incumbent on a resettled refugee to prove individually that he/she meets the criteria set out in the Geneva Convention. The means by which the two groups arrive in Ireland differ enormously, with asylum seekers often engaging on protracted journeys and finding individual and sometimes unofficial ways of entering the country. Whilst it is not illegal to seek asylum, many states in the EU continue to detain asylum seekers on various grounds including their 'illegal entry to the state'. The right to detain asylum seekers under certain conditions was upheld in the ECHR judgment in Saadi v. UK, where the majority judgment upheld the detention and justified it as not being disproportionate or arbitrary, nor in contravention of Article 5(1)(f) ECHR. ${ }^{79}$

Whilst resettled refugees may have engaged in protracted and difficult journeys before being accepted by the UNHCR and the Irish Government for resettlement, their journey into Ireland is generally organized and planned in advance, 
often in a group, with travel documents and assistance often provided by IOM. This more planned and orderly arrival into Ireland, in addition to the fact that they are invited (as opposed to arriving uninvited seeking asylum) also assists in the provision of planned and organized reception and integration supports.

The numbers accepted for resettlement are very small and in 2011 Ireland only accepted 45 in total. ${ }^{80}$ There was some evidence to suggest, for example, that some Iranian Kurds sought asylum in Ireland following the period that a group of Iranian Kurds were resettled in Ireland and some Iranian Kurdish asylum seekers were encountered in hostels close to areas where the resettled group of refugees were living. ${ }^{81}$ It must nevertheless be acknowledged that a determination of refugee status is a very individualized process, and sharing the same ethnic background or country of origin does not equate to having similar protection needs, which vary according to current legal understandings of who is a refugee. ${ }^{82}$

Whilst the protection needs of such groups cannot be equated, their integration needs once living in Ireland may be similar. Supports such as cultural orientation, language training and opportunities to integrate are important for both groups, especially as asylum seekers may spend many years in the system and those who are granted refugee status or other forms of protection may make Ireland their longterm home. The UNHCR has also recognized the role that integration and reception supports play for asylum seekers and in its report on Refugee Integration in Ireland, it concluded:

The reception facilities, length of the procedure and reception policies can play an important role in either aiding or impeding the integration of refugees. Specific recommendations include that reception policies should minimize isolation and separation from host communities, that effective language and vocational skills development should be provided and that the pursuit of employment should be assisted. Access to employment should be granted progressively, taking into account the duration of asylum procedures. $^{83}$

Host communities may fail to draw accurate distinctions between the two groups and a dichotomy can emerge when service providers are asked to treat each differently without a full understanding of the differences between them. ${ }^{84}$ It is also important to provide a clear message of welcome and shunning any forms of racism is essential in order to avoid ethnic or racial tensions. It has been suggested that the current system of exclusion of asylum seekers counteracts attempts to address racism and that 'the incompatibilities between a state's goals of challenging racism through the promotion of integration and interculturalism and punitive policies directed at one of the groups most vulnerable to racism in Irish society must be acknowledged'. 85

Previously the Reception and Integration Agency was responsible for both the accommodation of asylum seekers (reception function) and for the reception and integration of resettled refugees. Since 2011 however, the agency has been split and the functions relating to resettled refugees have been transferred to the Office for the Promotion of Migrant Integration.

Some of the key differences in the reception conditions of asylum seekers and resettled refugees are summarized in table 2 .

Is the Extent of Such Differentiation Proportionate? Under Irish and international law, resettled refugees are already recognized as refugees, whereas asylum seekers must first enter a process in which they attempt to assert that right. Differentiation between the two groups is therefore justifiable. It is asserted here however that the extent of such differentiation is disproportionate and the resulting dichotomy of those perceived as 'deserving' or 'undeserving' too stark and contradictory messages are conveyed. Official discourse relating to asylum seekers is exclusionary and risks furthering racism and social exclusion. On the other hand Ireland is proud of its tradition of accepting resettled refugees and undertakes missions to refugee camps to assist in the choice of those it perceives to be deserving, leaving behind others who could potentially travel independently as an asylum seeker. The model of support for reception and integration exists, but is confined to a small minority. I would therefore argue that certain aspects of it (e.g. basic information about life in Ireland and cultural issues) should be extended to asylum seekers at least after a period of six months, in conjunction with the right to work. Such reception supports would have wider benefits, foster independence and may also assist interactions with and integration with the host community.

Asylum-seekers in Norway, Finland and Sweden are generally provided with state sponsored language training, information programs and work permits. Authorities in Sweden and Norway have noted that "these facilitators of integration are deployed in order to empower asylum seekers and prepare them for life outside the reception facilities, whether that might be in the host country, their home country or somewhere else". 86 The approach the Irish authorities take is in direct contrast to this and concepts such as "facilitators of integration" or "empowerment of asylum seekers" do not find resonance in official discourse. Instead the focus appears to be on immigration control, and as a Department of Justice official stated in response to being 
Table 2. Difference in Reception Conditions of Asylum Seekers and Resettled Refugees in Ireland

\begin{tabular}{|c|c|c|}
\hline & Asylum Seekers & Resettled Refugees \\
\hline Housing & $\begin{array}{l}\text { Direct provision accommodation centres, } \\
\text { often on the outskirts of small towns. Whole } \\
\text { families share rooms and single people or } \\
\text { one parent families may share rooms with } \\
\text { strangers. }\end{array}$ & $\begin{array}{l}\text { Refugee training centre for first } 6 \text { weeks and } \\
\text { then transferred to private accommodation in } \\
\text { the community, usually paid for through rent } \\
\text { allowance. }\end{array}$ \\
\hline Income support & $\begin{array}{l}€ 19.60 \text { per adult and } € 9.60 \text { per child per week. } \\
\text { Three meals per day provided. Not entitled to } \\
\text { additional allowances such as child benefit. }\end{array}$ & $\begin{array}{l}\text { Same initial income supplement as unem- } \\
\text { ployed people in Ireland, usually the supple- } \\
\text { mentary income allowance of approximately } \\
€ 186 \text { per week per adult. Other allowances } \\
\text { apply, including child benefit. }\end{array}$ \\
\hline Education and Training & $\begin{array}{l}\text { Children attend school and may qualify for } \\
\text { language support. Adults not automatically } \\
\text { entitled to participate in language classes, } \\
\text { but sometimes free classes provided by } \\
\text { NGOs. }\end{array}$ & $\begin{array}{l}\text { Children attend school and may qualify for lan- } \\
\text { guage support. Adult language training free } \\
\text { for } 12 \text { to } 18 \text { months for } 20 \text { hours per week. }\end{array}$ \\
\hline Integration Supports & $\begin{array}{l}\text { NGOs may provide supports, but no European } \\
\text { Refugee Fund and other public funds only to } \\
\text { be used for minimal reception supports and } \\
\text { not for integration. }\end{array}$ & $\begin{array}{l}\text { Refugee support worker post in local develop- } \\
\text { ment agency for up to } 18 \text { months. NGOs may } \\
\text { also assist. }\end{array}$ \\
\hline Orientation Training & None provided. & 6 weeks cultural orientation. \\
\hline Right to Attend Third Level & Not entitled to. & $\begin{array}{l}\text { Entitled to attend. In some cases habitual } \\
\text { residence requirement of } 3 \text { years needed to } \\
\text { qualify for free fees, but this may be under } \\
\text { review. }\end{array}$ \\
\hline Right to work & $\begin{array}{l}\text { No right to work at any stage of the asylum- } \\
\text { seeking process. }\end{array}$ & $\begin{array}{l}\text { Entitled to work immediately but may be } \\
\text { delayed during the period of language } \\
\text { training. }\end{array}$ \\
\hline
\end{tabular}

Information retrieved from Citizens Information Board, Refugee Status and Leave to Remain, http://www.citizensinformation.ie/en/ moving_country/asylum_seekers_and_refugees/refugee_status_and_leave_to_remain/ (accessed December 8, 2011).

questioned about the low rates of recognition or asylum claims in Ireland, that the Government "was determined to address the high level of abuse of the asylum process by people seeking to gain entry to the State for purposes other than protection". 87

The presumptions in official discourse emanating from the Department of Justice in relation to the asylum system include: (i) The asylum system is open to abuse and must be protected from such abuse at all costs; (ii) in order to do so, it is necessary to make life difficult for asylum seekers here in order to remove incentives for asylum shopping or creating pull factors ${ }^{88}$; and (iii) allowing asylum seekers to work, train or instigating other such "integration facilitators" would detract from the purpose of the asylum system and there is little point in making such investments when the large majority of asylum seekers will ultimately be deported or asked to leave the state. The current fiscal difficulties have further exacerbated the situation.
Whilst many EU countries do have some timeframe in which asylum seekers may not have the right to work and are required to stay in collective accommodation centres, this situation is not usually as protracted as in Ireland. The long-term impacts on children and the unsuitability of the environment for parenting and raising children have been highlighted by many. ${ }^{89}$ Breen has argued that the direct provision scheme constitutes discrimination, as set down in the Refugee Convention (1951) and further expanded by the Committee on Human Rights, and under Article 2 of the ICESCR. ${ }^{90}$ Whilst the right to equality underpins all human rights instruments, it is not absolute and legitimate differential treatment is sometimes justified on the grounds of state sovereignty, which must also recognize the inherent dignity of the human person. The application of human rights law to immigration and asylum-related issues can be challenging for a number of reasons, including the resistance of governments to such approaches, the shortcomings of human rights law itself including the fact that there 
are often immigration exceptions carved into the rights themselves. ${ }^{91}$

Laws or policies that may infringe on human rights are bound by the principle of proportionality, recognized in national and international law. Under such a principle, the law in question should be adequate for the reason it was intended, necessary and proportionate in the sense of being reasonable. ${ }^{92}$ I would argue that the de facto implementation of the Direct Provision scheme through the Social Welfare (Consolidation) Act, 2005 and the Habitual Residence Clause for such prolonged periods is contrary to the intention of the original policies, aimed at alleviating a potential housing crisis (introduction of Direct Provision) and at deterring welfare tourism in the EU (in the case of the HRC). It would appear that reception policies for asylum seekers, developed at a time when there was a risk of homelessness and numbers were far greater, no longer serve the original aim for which they were intended. It could also be concluded that the effects of such reception conditions on a long-term basis (when originally intended as a temporary measure) are disproportionate and carry unintended negative consequences. The extremely low levels of support provided to asylum seekers during their prolonged reception phase is also disproportionate to the relatively high levels of support given to resettled refugees and are contrary to their long-term integration. It should not however be argued that their levels of support are too high and they are within the norms recommended by the UNHCR guidelines on resettlement. ${ }^{93}$

Many of the difficulties however in relation to the Direct Provision scheme relate to the length of time spent in it, which is not determined by the refugee application procedures (usually within one year), but the delays in subsequent applications for subsidiary protection or leave to remain. This is in contrast to the UK where asylum applications are expected to be concluded within six months, after which time a person can commence their integration into 'life in the UK' including the right to work. ${ }^{94}$ It is expected that the reforms of the procedures in the proposed IRP Bill in Ireland will alleviate some of these delays, but without retrospective effect, it is unlikely that it will apply to those currently in the system and no plans have been mooted to provide a fast track process for them.

Ireland has been criticized by the Committee on the Elimination of Racial Discrimination in relation to the need to adopt more measures to avoid negative consequences for asylum seekers, ${ }^{95}$ and by the Commissioner for Human Rights $^{96}$ in relation to the need for more suitable family accommodation and also urged the Irish Government to address issues of poverty, lack of personal autonomy, right to work and length of time spent in the asylum process.
It is interesting however when one considers that Ireland is the only EU country that has not ratified the EU Minimum Standards Directive, yet it is one of now thirteen countries in the EU voluntarily participating in the UNHCR Resettlement Programme and was one of the first EU countries to join the programme. This dichotomy of restrictive asylum policies versus relatively generous resettlement conditions can be difficult to reconcile, but on closer examination, it is clear that the process of resettlement (with an annual quota of 200, which is not always reached) is a much smaller and more controlled process and provides the State with a sense that it is meeting its international protection obligations in a more controlled manner. Asylum seekers numbers by contrast are at least ten times higher each year (although now decline) and the process by its nature is more complex, ad hoc and more difficult to control.

\section{Conclusion}

The two processes of resettlement and seeking asylum under the Convention are entirely separate and a comparison between the two groups in a strict legal sense is not possible. Under the resettlement process, the designation of people as deserving of refugee status has already been made (by the UNHCR) and the Irish Government is then able to choose a very small group of people who have been selected as "suitable for resettlement". Asylum-seekers on the other hand arrive with no international backing, often limited documentation and by means that can be complex and unofficial. There appears to be a presumption in official discourse that their claims are not valid, also shown in Ireland's very low acceptance rate in comparison with other EU countries. Under international law, their right to seek asylum is entirely valid and lawful. Once this claim is proven, they are then theoretically entitled to the same international protection and freedom from refoulement in the same manner as resettled refugees.

I have argued here that reception by its nature takes place when a person arrives in a country or within a period of six months and delaying this process for several years is contrary to its very purpose. It would be reasonable if asylum claims were processed within six months and the reception phase (including a right to work) commenced after such a period. The current protracted situation mainly due to adjudication of claims for other forms of protection is untenable and delaying reception and integration supports for several years is inhumane. The extent of the differences in reception conditions between resettled refugees and asylum seekers are disproportionate, particularly when the length of time is taken into consideration. Secondly the messages conveyed in relation to those who are deserving/undeserving and the manner in which Ireland treats 
its human rights obligations towards those seeking protection are contradictory and confusing. This paper is not suggesting that reception conditions for resettled refugees are too high, but rather that some aspects of their reception model should equally be provided to asylum seekers during the reception phase and at a minimum after six months of residence in Ireland.

\section{NOTES}

1. Under Ireland's dual system, an application for asylum under the Convention must be made first before a subsequent application for subsidiary protection or humanitarian leave to remain can be made. For the purpose of this paper, the term 'asylum seeker' encompasses all applicants, regardless of the stage of the legal process as they are all housed in the same reception hostels and have the same limited entitlements until a final outcome is made on their claim(s).

2. Hathaway, James C. The Rights of Refugees under International Law. (Cambridge [England]; New York: Cambridge University Press, 2005), See also Saadi v UK (Application No 13229/03) 29 January 2008 (Grand Chamber Decision) that upheld the right to detain asylum seekers until their entry was 'authorized'.

3. See for example Free Legal Advice Centres, One Size Doesn't Fit All: A Legal Analysis of the Direct Provision and Dispersal System in Ireland, 10 Years On (FLAC: Dublin 2009); Liam Thornton, "Upon the Limits of Rights Regimes" : Reception Conditions of Asylum Seekers in the Republic of Ireland," Refuge 24, no. 2 (2007): 86-100; Claire Breen, "The Policy of Direct Provision in Ireland: A Violation of Asylum Seekers' Right to an Adequate Standard of Housing," International Journal of Refugee Law 20, no. 4 (2008): 611-36; Hans. Pieper, Pauline Clerkin, and Anne Mac Farlane, The Impact of Direct Provision Accommodation for Asylum Seekers on Organization and Delivery of Local Health and Social Care Services: A Case Study (Galway: Department of General Practice, NUI Galway, 2009).

4. RIA, Reception and Integration Agency Monthly Statistics Report, June 2011, Dublin: Reception and Integration Agency, http://www.ria.gov.ie/en/RIA/RIAJune(A4)2011. pdf/Files/RIAJune(A4)2011.pdf (accessed December 8, 2011)

5. Ireland was recently questioned on this during a universal periodic review of Ireland under the UN Convention against Torture and Other Cruel, Inhuman or Degrading Treatment or Punishment. ICCL and IPRT, Joint Shadow Report to the First Universal Periodic Review of Ireland under the United Nations Convention against Torture and Other Inhuman, Cruel or Degrading Treatment or Punishment (Dublin: Irish Council for Civil Liberties, Irish Penal Reform Trust, 2011).
6. There are now 25 countries worldwide who participate in the UNHCR Resettlement Programme. The EU countries who have participated include Finland, the Netherlands, Sweden, Norway, the UK and Ireland. Recently resettlement programmes have been announced in the Czech Republic, France, Hungary, Portugal, Spain and Romania. See UNHCR, Frequently Asked Questions about Resettlement, Geneva, UNHCR http://www.unhcr.org/4ac0873d6. html (accessed June 21, 2012).

7. Office of the Promotion for Migrant Integration, Resettlement Programme: Introduction, Dublin: Office of the Promotion of Migrant Integration http://www.integration.ie/ website/omi/omiwebv6.nsf/page/resettlement-intro-en (accessed December 8, 2011)

8. The entitlement to subsidiary protection stems from the transposition of European Council. "Council Directive 2004/83/EC of 29 April 2004 on Minimum Standards for the Qualification and Status of Third Country Nationals or Stateless Persons as Refugees or as Persons Who Otherwise Need International Protection and the Content of the Protection Granted.", 2004. It can be granted to those at risk of 'serious harm' if returned to their country of origin. Between 2006 and 2010, only 34 grants of subsidiary protection were made.

9. An application for Leave to Remain on humanitarian grounds can be made under Section 3 of the Immigration Act, 1999.

10. See UNHCR, Refugee Resettlement: An International Handbook to Guide Reception and Integration (Geneva: Office of the United Nations High Commissioner for Refugees, 2002).

11. Denise Thomsson, "An Institutional Framework on Resettlement." In Resettled and Included: The Employment Integration of Resettled Refugees in Sweden, ed. P. Bevelander, M. Hagstrom and S. Ronnqvist. (Malmo: Malmo University, 2008); Marita Eastmond, "Egalitarian Ambitions, Constructions of Difference: The Paradoxes of Refugee Integration in Sweden" Journal of Ethnic and Migration Studies 37, no. 2 (2011): 277-95.

12. International human rights monitoring processes that have raised concerns in relation to reception conditions for asylum seekers include Commissioner for Human Rights reports in 2007 and 2011, (Council of Europe) See Commissioner for Human Rights. "Report on Visit to Ireland 26-30 November 2007." Strasbourg: Council of Europe, 2008, Commissioner for Human Rights. "Report on Visit to Ireland 1-2 June 2011." Strasbourg: Council of Europe, 2011. The UNHRC Special Rapporteur on Extreme Poverty also raised concerns about the poverty of families and children in the system. See UNHRC. "Report of the Independent Expert on the Question of Human Rights and Extreme Poverty, Magdalena, Sepulveda, Carmona: Mission to Ireland." A/HRC/17/34/Add.2 (2011), http://www2. ohchr.org/english/bodies/hrcouncil/docs/17session/A. HRC.17.34.Add.2_en.pdf. 
13. An analysis of the impact of the system on families, mothers and children are contained in reports such as Akidwa. "Am Only Saying It Now: Experiences of Women Seeking Asylum in Ireland." Dublin: Akidwa, 2010. Uchechukwu Ogbu, Helen. "An Explorative Study of the Experiences of Asylum Seekers in Rearing Their Children in Direct Provision Centres." NUI Galway, 2011. Breen, Claire. "The Policy of Direct Provision in Ireland: A Violation of Asylum Seekers' Right to an Adequate Standard of Housing." International Journal of Refugee Law 20, no. 4 (2008): 611-36.

14. Moreo, Elena, and Ronit Lentin. "From Catastrophe to Marginalization: The Experience of Somali Refugees in Ireland." Dublin: Migrant Networks Project, (Trinity Immigration Initiative, 2010).

15. Council Directive 2004/83/EC of 29 April 2004 on minimum standards for the qualification and status of third country nationals or stateless persons as refugees or as persons who otherwise need international protection and the content of the protection granted

16. The 2010 Immigration, Residence and Protection Bill proposed a single determination procedure. A new bill is expected to be introduced in late 2012 or early 2013.

17. Examples of towns where both have been housed include Ballyhaunis Co. Mayo, (the resettled refugee training centre), Sligo and Ballinamore/Carrick on Shannon in County Leitrim. Carrick and Shannon and Sligo formed part of the MOST research project for Ireland. See Louise Kinlen, "The Reception, Orientation and Integration of Resettled Refugees in the Irish Context, Most Project Report: Ire land." (2008), http://www.integration.ie/website/omi/ omiwebv6.nsf/page/AXBN-7TCEAY11284425-en/\$File/ MOST_Project\%20-\%20final_Ireland.pdf. The issue of entitlements of both groups was raised in interviews with NGOs and civil servants both during this research project and in the current research on NGO advocacy and policy making. For a discussion on childcare service provision for the two groups and confusion over entitlements, see also Nicola Dolan, and Catherine Sherlock, "Family Support through Childcare Services: Meeting the Needs of AsylumSeeking and Refugee Families." Child Care in Practice 16, no. 2 (2010): 147-65.

18. National Consultative Committee on Racism and Interculturalism. "Submission to the Interdepartmental Working Group on the Integration of Refugees in Ireland." Dublin: NCCRI, 1999.

19. Ibid, Section 2.2

20. Mestheneos, E., and E. Ioannidi. "Obstacles to Refugee Integration in the European Union Member States." Journal of Refugee Studies 15, no. 3 (2002): 304-20.

21. See Liam Thornton, "Upon the Limits of Rights Regimes" : Reception Conditions of Asylum Seekers in the Republic of Ireland," Refuge 24, no. 2 (2007): 86-100; Claire Breen, "The Policy of Direct Provision in Ireland: A Violation of Asylum Seekers' Right to an Adequate Standard of Housing," International Journal of Refugee Law 20, no. 4 (2008):
611-36; Brian Fanning, Brian, Angela Veale, and Dawn O'Connor, Beyond the Pale: Asylum-seeking Children and Social Exclusion in Ireland (Dublin: Irish Refugee Council 2001).

22. See www.integration.ie

23. Under Section 9(4) of the Refugee Act, 1996 a person seeking protection may not leave the country without consent of the Minister for Justice.

24. Hathaway, James C. "Why Refugee Law Still Matters." Melbourne Journal of International Law, no. 25th Allen Hope Southey Memorial Lecture (2007): 89-103.

25. UNHCR, UNHCR Comments on the European Commission's Proposal for a recast of the Directive laying down minimum standards for the reception of asylum-seekers (COM (2008)815 final of 3 December 2008) http://www. unhcr.org/cgi-bin/texis/vtx/home/opendocPDFViewer. html?docid=49be19db2\&query=reception conditions EU

26. European Council. “Council Directive 2003/9/EC Laying Down Minimum Standards for the Reception of Asylum Seekers." (2003).

27. UNHCR, Reception Standards for Asylum Seekers in the European Union (Geneva: Office of the UN High Commissioner for Refugees, 2000).

28. Lentin, Ronit, and Robbie Mc Veigh. After Optimism? Ireland, Racism and Globalization. Dublin: Metro Eireann Publications, 2007.

29. This transnational project was funded under the Community Actions Strand of the European Refugee Fund. The final report is available on Louise Kinlen, The Reception, Orientation and Integration of Resettled Refugees in the Irish Context, Most Project Report: Ireland (2008), http://www. integration.ie/website/omi/omiwebv6.nsf/page/AXBN -7TCEAY11284425-en/\$File/MOST_Project\%20-\%20final_ Ireland.pdf (accessed December 8, 2011)

30. Ibid. Whilst the report was produced under a project under the auspices of the Office of the Minister for Integration, the views expressed in this paper are the author's own.

31. See supra note 21 and Peter Fell, "And now it has started to rain: Support and advocacy with adult asylum seekers in the voluntary sector" in Social work, immigration and asylum : debates, dilemmas and ethical issues for social work and social care practice, ed. Debra Hayes, Beth Humphries and Steven Cohen. (London: Jessica Kingsley, 2004).

32. See for example supra note 28. The term 'reception' is used to refer to the agency in Ireland with responsibility for receiving asylum seekers The Reception and Integration Agency. It is also referred to as a distinct stage within the resettlement process. See for example http://www.integration .ie/website/omi/omiwebv6.nsf/page/83D9DD3235CC6B2E 802575750063B3FA (accessed December 8, 2011).

33. Council Directive 2003/9/Ec Laying Down Minimum Standards for the Reception of Asylum Seekers European Council (2003).

34. UNHCR, Discussion Paper on Recommended Reception Standards for Asylum-Seekers in the Context of the 
Harmonization of Refugee and Asylum Policies of the European Union (Geneva: UNHCR, 2000).

35. Liam Thornton, "“Upon the Limits of Rights Regimes": Reception Conditions of Asylum Seekers in the Republic of Ireland." Refuge 24, no. 2 (2007): 86-100.

36. Kinlen, L. "The Reception, Orientation and Integration of Resettled Refugees in the Irish Context, Most Project Report: Ireland." (2008), http://www.integration.ie/ websit e/o mi / o miwebv6.nsf/ page/ A X B N -7TCEAY11284425-en/\$File/MOST_Project\%20-\%20final_ Ireland.pdf.

37. Moreo, Elena, and Ronit Lentin. "From Catastrophe to Marginalization: The Experience of Somali Refugees in Ireland.” Dublin: Migrant Networks Project, Trinity Immigration Initiative, 2010.

38. Maguire, Mark, and Gavin Titley. "The Body and Soul of Integration." Translocations: Migration and Social Change 6, no. 1 (2010): 1-19. Lentin, Ronit, and Elena Moreo. "Conclusion: Integration from Below?" In Migrant Activism and Integration from Below in Ireland, 182-201: Palgrave Macmillan, 2012.

39. Pia Prutz Phiri, "UNHCR, International Refugee Protection and Ireland," in Sanctuary in Ireland: Perspectives on Asylum Law and Policy, ed. U. Fraser and C. Harvey (Dublin: IPA, 2003).

40. Paul O’Mahony, “Supporting Asylum Seekers," in Sanctuary in Ireland: Perspectives on Asylum Law and Policy, ed. U. Fraser and C. Harvey (Dublin: IPA, 2003).

41. Brian Fanning and Fidele Mutwarasibo, "Nationals/NonNationals: Immigration, Citizenship and Politics in the Republic of Ireland," Ethnic and Racial Studies 30, no. 3 (2007).

42. RIA, "Reception and Integration Agency: Background," http://www.ria.gov.ie/en/RIA/Pages/Background (accessed December 8, 2011).

43. See ibid. The integration function of the agency was later transferred to the Integration Unit of the Office of the Minister for Integration, now renamed the Office of the Promotion of Migrant Integration, which still excludes asylum seekers from its brief. See Office of the Promotion of Migrant Integration "About Us," http://www.integration.ie (accessed December 8, 2011).

44. Supra note 36.

45. Supra note 42.

46. Free Legal Advice Centres. "Flac Submission on the Habitual Residence Condition to the Joint Oireachtas Committee on Social Protection." Dublin: FLAC, 2010

47. Source: Eurostat. "Eurostat News Release: Asylum Decision in Eu27 2011." Eurostat, http://epp.eurostat. ec.europa.eu/cache/ITY_PUBLIC/3-19062012-BP/EN/319062012-BP-EN.PDF.

48. Galway Refugee Support Group. "Submission on the Irish Government's Report to the Committee on the Elimination of Racial Discrimination." (Galway: GRSG, 2010).
49. See Department of Justice, Equality and Law Reform. "National Action Plan on Against Racism 2005-2008" (Dublin: DJELR, 2005); Department of Social and Family Affairs. "National Action Plan for Social Inclusion 20072016" (Dublin: DSFA, 2007); DoHC. "Our Children, Their Lives: The National Children's Strategy.” (Dublin: Department of Health and Children, 2000).

50. Ibid.

51. This view was expressed for example by interviewees from the Health Service Executive and other Government agencies, speaking in a personal capacity. These interviews were conducted in late 2011/early 2012 as part of the doctoral research on NGO advocacy and policy making.

52. Free Legal Advice Centres. "Direct Discrimination? An Analysis of the Scheme of Direct Provision in Ireland." (Dublin: Free Legal Aid Centres 2003). Fanning, B., A. Veale, and D. O'Connor. "Beyond the Pale: Asylum-Seeking Children and Social Exclusion in Ireland." (Dublin: Irish Refugee Council, 2001).

53. Research interviews with NGOs in the 2nd research project confirmed their frustration in relation to limited policy progress and a sense that neither they nor the criticisms of the international community in relation to the lack of autonomy for asylum seekers have been taken on board.

54. Lentin, Ronit. "Ireland: Racial State and Crisis Racism." Ethnic \& Racial Studies 30, no. 4 (2007): 610-27. Mark Maguire and Gavin Titley 'The Body and Soul of Integration,' Translocations: Migration and Social Change, 6 (1): 1-19 (2010)

55. Supra, note 4

56. See Denise Thomsson, "An Institutional Framework on Resettlement." In Resettled and Included: The Employment Integration of Resettled Refugees in Sweden, ed. P. Bevelander, M. Hagstrom and S. Ronnqvist. (Malmo: Malmo University, 2008); M. Eastmond, "Egalitarian Ambitions, Constructions of Difference: The Paradoxes of Refugee Integration in Sweden." Journal of Ethnic and Migration Studies 37, no. 2 (2011): 277-95.

57. Hans. Pieper, Pauline Clerkin, and Anne Mac Farlane, The Impact of Direct Provision Accommodation for Asylum Seekers on Organization and Delivery of Local Health and Social Care Services: A Case Study (Galway: Department of General Practice, NUI Galway, 2009).

58. Claire Breen, "The Policy of Direct Provision in Ireland: A Violation of Asylum Seekers' Right to an Adequate Standard of Housing," International Journal of Refugee Law 20, no. 4 (2008): 611-36

59. Ibid; Brian Fanning, Brian, Angela Veale, and Dawn O'Connor, Beyond the Pale: Asylum-seeking Children and Social Exclusion in Ireland (Dublin: Irish Refugee Council 2001); Supra note 32; Alan White, "Every Wednesday I Am Happy: Childhoods in an Irish Asylum Centre," Population, Space and Place (2011), http://onlinelibrary.wiley.com/ doi/10.1002/psp.659 (accessed December 8, 2011). 
60. See e.g. John Waters, "Masks Slips on Pious Humbug of Child Rights." Irish Times, July 31, 2010; Patricia Mc Donagh, "All-party pact over children's referendum scrapped," Irish Independent" October 14, 2010.

61. Mc Adam, Jane. "Complementary Protection in International Refugee Law." In Oxford Monographs in International Law. Oxford: Oxford University Press, 2007.

62. Mc Adam, Jane. "Seeking Asylum under the Convention on the Rights of the Child: A Case for Complementary Protection." International Journal of Children's Rights 14, no. 3 (2006): 251-74. See also Committee on the Rights of the Child (2005) 'General Comment No. 6 on Treatment of Unaccompanied and Separated Children Outside Their Country of Origin'U.N. Doc.CRC/GC/2005/6 (1 September 2005).

63. Free Legal Advice Centres, One Size Doesn't Fit All: A Legal Analysis of the Direct Provision and Dispersal System in Ireland, 10 Years On (FLAC: Dublin 2009)

64. Akidwa, Am Only Saying It Now: Experiences of Women Seeking Asylum in Ireland (Dublin: Akidwa, 2010); Liam Thornton, “'Upon the Limits of Rights Regimes" : Reception Conditions of Asylum Seekers in the Republic of Ireland." Refuge 24, no. 2 (2007): 86-100. Brian Fanning, Brian, Angela Veale, and Dawn O'Connor, Beyond the Pale: Asylum-seeking Children and Social Exclusion in Ireland (Dublin: Irish Refugee Council 2001). FLAC, “One Size Doesn't Fit All: A Legal Analysis of the Direct Provision and Dispersal System in Ireland, 10 Years On." (Dublin: Free Legal Advice Centres, 2009).

65. This was a common issue raised in interviews with immigration NGOs as part of the research on NGO advocacy and its influence on policy making.

66. Commissioner for Human Rights, Report on Visit to Ireland 26-30 November 2007, (Strasbourg: Council of Europe, 2008); Supra note 31; Akidwa, Am Only Saying It Now: Experiences of Women Seeking Asylum in Ireland (Dublin: Akidwa, 2010).

67. RIA, Value for Money Report and Policy Review: AsylumSeeker Accommodation Programme, Dublin: Reception and Integration Agency, 2010, http://www.ria.gov.ie/en/ RIA/FINAL\%20VFM\%20Report\%20on\%20Asylum\%20 Seeker\%20Accomm\%20July272010.pdf/Files/FINAL\%20 VFM\%20Report\%20 on\%20 Asylum\%20Seeker\%20 Accomm\%20July272010.pdf (accessed December, 8, 2011).

68. Jamie Smyth, "Fine Gael and Labour Pledge to Review Asylum System," Irish Times, July 8, 2010.

69. UNHCR, UNHCR Urges Ireland to Resettle More Refugees 25 Years after First Vietnamese Arrive, UNHCR News Stories, Geneva: UNHCR, http://www.unhcr.org/40dad4b94. html (accessed December 8, 2011).

70. Supra note 41.

71. Searches were undertaken of the terms 'programme' or 'resettled' refugees and Ireland in Dáil debates, online newspaper databases and academic databases. In comparisons with similar searches using the term "asylum seeker", the number of results returned was very low.

72. See e.g. UNHCR, UNHCR Praises Kilkenny for Its Support to Resettled Refugees, UNHCR News Stories, UNHCR: Geneva, http://www.unhcr.ie/220609.html (accessed December 8, 2011); Editorial, "78 Burmese Refugees to Be Resettled in Ireland," Irish Times, February 2, 2009.

73. Office for the Promotion of Migrant Integration, The Irish ResettlementProcess, Office for thePromotion of MigrantIntegration: Dublin, http://www.integration.ie/website/omi/ omiwebv6.nsf/page/resettlement-irishresettlementproc -en (accessed December 8, 2011).

74. Louise Kinlen, The Reception, Orientation and Integration of Resettled Refugees in the Irish Context, Most Project Report: Ireland, Dublin: RIA, 2008, http://www. integration.ie/website/omi/omiwebv6.nsf/page/AXBN -7TCEAY11284425-en/\$File/MOST_Project\%20-\%20final_ Ireland.pdf (accessed December 8, 2011).

75. Ibid.

76. Ibid.

77. UNHCR, Mapping Integration: UNHCR's Age, Gender and Diversity Mainstreaming Project on Refugee Integration in Ireland-2008/2009, (Dublin: UNHCR, 2009).

78. For information on training possibilities for Convention refugees see Office of the Promotion of Migrant Integration. Adult Refugee Programme, Dublin, 2012, http://www. integration.ie/website/omi/omiwebv6.nsf/page/managingdiversity-AdultRefugeeProgramme-en (accessed June 24, 2012).

79. Saadi v UK (Application No 13229/03)29 January 2008 (Grand Chamber Decision). See also Stevens, Dallal. "The Law's Approach to Detention of Asylum Seekers: Help or Hindrance?" In The Theory and Practice of Immigration Detention Workshop. (University of Oxford, 2010).

80. Eurostat. "Eurostat News Release: Asylum Decision in Eu27 2011." Eurostat, http://epp.eurostat.ec.europa.eu/cache/ ITY_PUBLIC/3-19062012-BP/EN/3-19062012-BP-EN. PDF (accessed June 21, 2012)

81. During 2005-2006 226 Iranian Kurds were resettled in Ireland. See RIA, Resettlement of Programme Refugees-2000-2011, http://integration.ie/website/omi/omiwebv6.nsf/page/resettlement-overviewofrecentrefugeeresettlementprogrammes2000-2011-en (accessed June 21, 2012).

82. For a further discussion on what is meant by protection and how it is linked to who the dominant legal understanding of who is a refugee, see Jane Mc Adam, "Complementary Protection in International Refugee Law." In Oxford Monographs in International Law. (Oxford: Oxford University Press, 2007).

83. UNHCR. "Mapping Integration: UNHCR's Age, Gender and Diversity Mainstreaming Project on Refugee Integration in Ireland-2008/2009." (Dublin: UNHCR, 2009), p.27. 
84. This issue of different entitlements for various groups was raised as a difficulty by service providers at various meetings/seminars at which the author was present and in research interviews.

85. Brian Fanning and Angela Veale, Child Poverty as Public Policy: Direct Provision and Asylum Seeker Children in the Republic of Ireland, (Dublin: Irish Refugee Council, 2001).

86. Marko Valenta and Nihad Bunar, "State Assisted Integration: Refugee Integration Policies in Scandinavian Welfare States: The Swedish and Norwegian Experience," Journal of Refugee Studies 23, no. 4 (2010) 463-83.

87. Supra note 70.

88. The creation of pull factors is frequently mentioned in Dail debates 2001-2012. See e.g. Dail Debates. "Written Answers-Asylum Applications. Thursday, 2 February 2006." Dail Debates, http://debates.oireachtas.ie/ dail/2006/02/02/00068.asp. (accessed June 21, 2012), Dail Debates. "Adjournment Debate-Asylum Support Services, Tuesday, 19 July 2011" Houses of the Oireachais,, http:// debates.oireachtas.ie/dail/2011/07/19/00028.asp. (accessed June 21, 2012).

89. A recent study of the impact on direct provision on parenting found many negative consequences, with the direct provision system cited as the greatest source of difficulty for parents. Consequences included multiple and confusing role models for children in a communal environment, lack of control over the environment, belittling of parents by staff in front of children, lack of access to food when parents or children were sick, nutritional difficulties, overcrowding and lack of privacy and inability to integrate and for children to have normal lives. See Helen Uchechukwu Ogbu, An Explorative Study of the Experiences of Asylum
Seekers in Rearing Their Children in Direct Provision Centres, M.A. Thesis, Child and Family Studies, (NUI Galway, 2011).

90. Supra note 60.

91. Ciara Smyth"Why Is It So Difficult to Promote a Human Rights-Based Approach to Immigration." Irish Human Rights Law Review 1 (2010): 83-109.

92. Juan Cianciardo. 2009. "The Principle of Proportionality: its Dimensions and Limits” Expresso, http://works.bepress. com/juan_cianciardo/1 (accessed June 24, 2012).

93. UNHCR. "Refugee Resettlement: An International Handbook to Guide Reception and Integration ". (Geneva: Office of the United Nations High Commissioner for Refugees, 2002).

94. UK Home Office Border Agency, "Asylum", http://www. ukba.homeoffice.gov.uk/asylum/ (Accessed 24 June, 2012)

95. CERD, Concluding Observations of the Committee on the Elimination of Racial Discrimination, Ireland," in CERD/C/ IRL/CO/2 (2005).

96. Commissioner for Human Rights, Report on Visit to Ireland 26-30 November 2007, (Strasbourg: Council of Europe, 2008).

Louise Kinlen is a doctoral fellow in the UNESCO Child and Family Research Centre, NUI Galway. She is in receipt of funding from the Child and Youth Programme a joint initiative of the two UNESCO Chairs in the University of Ulster and the Child and Family Research Centre NUIG. 
(C) Louise Kinlen, 2011. This open-access work is licensed under a Creative Commons Attribution-NonCommercial 4.0 International License, which permits use, reproduction and distribution in any medium for non-commercial purposes, provided the original author(s) are credited and the original publication in Refuge: Canada's Journal on Refugees is cited. 